\title{
Peruskoulun jälkeinen koulutus uudistuu
}

Opetusministeriö on ollut viime aikoina aktiivisesti kehittämässä suomalaista koulutusjärjestelmää, kuten sen rooliin kuuluukin. Se laati viime tammikuussa muistion, jossa arvioitiin Suomessa harjoitetun koulutuspolitiikan tuloksia. Muistiossa hahmotettiin myös peruskoulun jälkeisen koulutuksen pitemmän aikavälin kehittämislinjoja. Suoritettu keskiasteen uudistus näyttää jäävän vain välivaiheeksi suuremman koulutusuudistuksen edellä, sillä lukioopetuksen, ammattikoulujen ja -opistojen sekä korkeakoulujen keskinäiset suhteet kaipaavat selvästi täsmentämistä. Näiden eri koulutustasojen oppisisällöt eivät vastaa kaikilta osin tämän hetken vaatimuksia ja siirtyminen koulutustasolta tai -muodosta toiseen on käytännössä suhteellisen hankalaa, vaikka se on periaatteessa mahdollista.

Opetusministeriö järjesti helmikuussa laajan koulutuspoliittisen seminaarin, joka käynnisti vilkkaan julkisen keskustelun erityisesti suunnitelluista nuorisokouluista ja ammattikorkeakouluista. Kovin selkeitä suunnitelmat eivät vielä ole, mutta ne tuntuvat kuitenkin oikeansuuntaisilta ja kehittelyn arvoisilta. Jonkinlaisen käsityksen niiden perusajatuksista saa mm. opetusministeriön julkaisusta Peruskoulun jälkeisen koulutuksen kehittäminen (OPM:n työryhmien muistioita 1989: 54).

Nuorisokoulusta suunnitellaan kolmivuotista, luokatonta, kurssimuotoista koulua, joka on vapaaehtoinen, mutta se-on tarkoitettu koko ikäluokalle. Se antaa jatko-opintokelpoisuuden sekä ammattikorkeakouluihin että tiedekorkeakouluihin ja yliopistoihin. Nuorisokoulussa opiskelija voi suorittaa nykyisen lukion kaltaisia opintoja tai toisaalta ammatillisia, huomattavasti nykyistä käytännöllisempiä työelämään orientoivia opintoja. Se tulisi sisältämään osittain opintoaịnepohjaista, mutta myös ongelmakeskeisiä projektiopintoja. Nuorisokoulun onnistuminen riippuu siitä, miten se pystyy motivoimaan opiskelijoita omaehtoiseen opiskeluun ja tiedonhankintaan. Nykyinen koulujärjestelmä ei ainakaan ole onnistunut tässä kovin hyvin. Tämä johtuu siitä, että opetus on edelleen esim. lukiossa varsin opettajakeskeistä ja tiukkoihin opetussuunnitelmiin pitäytyvää. Myös nykyinen ylioppilastutkinto on ohjannut opiskelua liiaksi mekaaniseen ulkoaoppimiseen. Tästä syystä ammattikorkeakouluihin suunniteltua päättötutkintoa tulisi vielä harkita, sillä se saattaa aiheuttaa samanlaista vinoutunutta tutkintopainotteisuutta syvällisempien oppimisprosessien kustannuksella.
Suunniteltujen ammattikorkeakoulujen ohjelmat käsittävät nykyiset ammatilliset korkeaasteen linjat ja opistoasteen linjat. Ammattikorkeakouluihin sijoitettaisiin myös korkeakoulujen yhteydessä oleva opistotutkintoon tai alempaan korkeakoulututkintoon johtava koulutus. Ammattikorkeakouluista voisi sitten siirtyä tiedekorkeakouluihin ja niissä suoritetut kurssit olisivat vertailukelpoisia tiedekorkeakoulujen opintojaksoihin. Ammattikorkeakoulujen opetus tulisi olemaan luonteeltaan tieteellistä, mutta tieteellisen tutkimuksen tekeminen jäisi pääasiassa edelleen tiedekorkeakoulujen ja yliopistojen tehtäväksi. Tämä selkiyttäisi eri oppilaitosten työnjakoa ja tiedekorkeakoulut ja yliopistot voisivat keskittyä enemmän tieteelliseen tutkimukseen, sen sijaan että ne nykyisin hoitavat osittain ammatillisille oppilaitoksille kuuluvia tehtäviä.

Ammattikorkeakoulut mahdollistaisivat opiskelijoiden siirtymisen koulutusasteelta toiselle aikaisempaa joustavammin. Ne merkitsisivät samalla välitutkintojen palauttamista korkeakouluopintoihin. Kuten tunnettua, välitutkinnot poistettiin aikoinaan tutkinnonuudistuksen yhteydessä, kun korkeakoulujen opetusta haluttiin tieteellistää kautta linjan. Nyt voidaan todeta, että ratkaisu ei ollut oikea, sillä korkeakoulututkinnot paisuivat tällöin kohtuuttomasti ja opiskeluajat pitenivät huomattavasti. Tämä on ajanut monet opiskelijat taloudelliseen ahdinkoon opiskeluaikanaan ja myös valmistumisensa jälkeen. Huonoimmassa asemassa ovat olleet se, jotka ovat joutuneet keskeyttämään opintonsa saamatta opintosuorituksistaan juuri mitään etua työmarkkinoilla. Välitutkintojen palauttaminen antaisi opiskelijalle mahdollisuuden siirtyä, jos hän niin hyväksi katsoo, työelämään joksikin ajaksi ja palata mahdollisesti myöhemmin suorittamaan ylemmän tutkinnon. Koska vastaavanlainen järjestelmä on käytössä jo useissa Euroopan maissa, niin uudet ammattikorkeakoulut antaisivat tutkinnon suorittaneille paremmat mahdollisuudet hyödyntää tutkintonsa myös kansainvälisillä työmarkkinoilla. Vuonna 1990 aloitetaan kokeiluvaihe, jossa on mukana 5-10 nuoriso- ja ammattikorkeakoulua. Tarkoitus on edetä vähitelleen erilaisia vaihtoehtoja kokeillen. Mielenkiinto ammattikorkeakoulukokeiluja kohtaan on ollut suuri ammatillisissa oppilaitoksissa. Aika näyttää mitkä ovat tulokset.

Nuorisokoulujen ja ammattikorkeakoulujen kehittämisen mielekkyyttä arvioitaessa tulisi keskeisenä kriteerinä olla se, miten niiden avulla onnistutaan kehittämään nuorten ikä- 
luokkien jatkuvia oppimisvalmiuksia ja -motivaatiota. Jos näillä uusilla koulutusmuodoilla pystytään parantamaan edellä mainittuja seikkoja ja opiskelijoiden joustavaa siirtymistä koulutustasolta toiselle, niin uudistuksia voi pitää tervetulleina. Uudistukset ovat myös aikuiskasvatuksen kannalta mielenkiintoisia ja merkittäviä, koska niiden vaikutukset näkyvät aikanaan myös aikuisten opiskelussa.

Viime kesäkuussa opetusministeriö asetti koulutuspolitiikan johtoryhmän alaisuuteen erillisen aikuiskoulutuksen johtoryhmän, jonka tehtävänä on tehostaa aikuiskoulutuksen kehittämistyötä, parantaa kouluhallinnon yhteistyötä aikuiskoulutuksen alueella sekä laatia koulutuspolitiikan johtoryhmälle luonnos aikuiskoulutuksen kehittämista koskevaksi toimenpideohjelmaksi. Aikuiskoulutuksen johtoryhmän puheenjohtajana on toiminut ylijohtaja Leevi Melametsä ja sen jäseninä ovat olleet ylijohtaja Markku Linna opetusministeriöstä, pääjohtaja Erkki Aho kouluhallituksesta sekä pääjohtaja Jorma Pöyhönen ammattikasvatushallituksesta. Johtoryhmä on siis ollut todellinen johtoryhmä runsaine sihteerityövoimineen. Johtoryhmän työ valmistui melko nopeasti, sen muistio "69 toimenpidettä aikuiskoulutuksen kehittämiseksi" ilmestyi marraskuun lopulla (Opetusministeriön työryhmien muistioita 1989: 59). Pitkälti muistio kirjaa jo monessa muussa yhteydessä esitettyjä ajatuksia. Sen suurin ansio lienee siinä, että uudistusesitykset on nyt koottu yhteen ja niiden toteuttamiselle on laaditty aikataulu. Muistioon on kirjattu myös uudistusten toimeenpanosta vastuussa olevat viranomaiset ja virastot. Mitään radikaaleja uudistuksia johtoryhmä ei esitä, mutta näidenkin toimenpiteiden toteuttaminen parantaa kyllä aikuisten opiskelumahdollisuuksia monilta osin. Uudistustoimenpiteet ovat kuitenkin lähinnä vain olemassa olevan järjestelmän paikkailua ja korjailua, uusia näkemyksiä ja linjavetoja ei muistiosta löydy.

Esitettyjen uudistustoimenpiteiden toteutuminen riippuu eduskunnasta ja siitä miten valtiontalouden kokonaistilanne maassamme kehittyy. Kuten tunnettua, koulutusmenot ovat yleensä ne, joista ensimmäiseksi tingitään, kun taloudellinen tilanne kiristyy. Näinhän kävi mm. 1970-luvun lopulla, jolloin aikuiskasvatuksen kehittäminen tyrehtyi taloudelliseen lamaan. Toivottavasti näin ei käy tällä kertaa. Muistion mukaan valtion osuudeksi arvioidut kustannusten lisäykset ovat vuosina 1990-91 yhteensä noin 350-400 miljoonaa markkaa vuodessa.

Uudistustoimenpiteet on ryhmitelty muistiossa neljään osaan: 1) kaikkia koulutusmuotoja koskevat toimenpiteet, 2) yleissivistävää aikuiskoulutusta koskevat toimenpiteet, 3) ammatillista aikuiskoulutusta koskevat toimenpiteet sekä 4) korkeakoulujen aikuiskoulutusta koskevat toimenpiteet. Eri aikuiskasvatussektoreilla toimivien on helppo tarkistaa muistiosta, minkälaisia toimenpiteitä omalla sektorilla on lähivuosina tarkoitus toteuttaa. Tässä ei ole mahdollista lähteä yksityiskohtaisesti tarkastelemaan kaikkia esityksiä, mutta jo yksistään sen toteaminen, miten paljon eri sektoreiden tutkimus- ja kehittämistoimintaan on suunnitelmassa esitetty varattavaksi määrärahoja kertoo kehittämistoiminnan painopistealueista. Vuodelle 1991 esitetään varattavaksi tutkimusja kehittämismäärärahoja seuraavasti: yleissivistävään aikuiskoulutukseen 3 miljoonaa markkaa, ammatilliseen aikuiskoulutukseen 20 miljoonaa markkaa ja korkeakoulujen aikuiskoulutukseen 6 miljoonaa markkaa. Kun otetaan huomioon, että korkeakoulujenkin kehittämistoiminta on lähinnä ammatillista aikuiskoulutusta, niin voidaan kysyä, ovatko yleissivistävän ja ammatillisen aikuiskoulutuksen kehittämiseen suunnitellut määrärahat oikeassa suhteessa keskenään?

Vaikka ymmärrän hyvin, että työ ja ammatillinen koulutus on keskeisessä asemassa useimpien aikuisten elämässä, niin mielestäni emme saa unohtaa myöskään heidän perussivistyksenä kohentamista. Sen parantaminen on tänä päivänä yhtä välttämätöntä aikuisten kuin nuortenkin kohdalla. Samoin aikuisten omaehtoisen kulttuuri- ja harrastustoiminnan sekä kriittisen ajattelun kehittäminen on ensiarvoisen tärkeää tässä pintapuolisen joukkotiedotuksen ja massaviihteen yhteiskunnassa. Jotenkin hämmästyttävää on myös se, että esim. Euroopan yhdentymiskehityksen yhteydessä on tuotu esiin vain ammatillisen aikuiskoulutuksen kehittämisen tarve. Sen sijaan esim. Euroopan eri valtioiden poliittis-yhteiskunnallisten järjestelmien ja kulttuurien ymmärtämistä parantavien opetusohjelmien kehittämisestä ei olla lainkaan kiinnostuneita. Olisi korkea aika ryhtyä pohtimaan myös tällaisia asioita, jotka koskevat laaja-alaisesti koko aikuisväestöä.

Jukka Tuomisto 